\section{DIARY}

\section{JANUARY 2010}

BDA seminar - Tender training

for orthodontists

Date: 15 January 2010

Venue: British Dental Association, London www.bda.org

British Academy of Cosmetic Dentistry Study Club: Impression free dentistry: are we there yet?

Date: 26 January 2010

Venue: British Dental Association, London www.bacd.com

\section{FEBRUARY}

The National Association of Prison Dentistry UK Annual Conference Date: 5 February 2010

Venue: Birmingham Botanical Gardens \&t Glasshouses

www.napduk.org

Dental Forum 2010

Date: 4-6 February 2010

Venue: Vincennes, The Parc Floral, Paris

www.dentalforum2010.com

BDA Seminar - Dentistry in the UK

Date: 11 February 2010

Venue: British Dental Association, London www.bda.org

American Institute of Implant Dentistry (AIID): Pathways to excellence in implant dentistry Date: 19-20 February 2010

Venue: Tenerife, Spain

www.implant-dentistry.com

\section{MARCH}

\section{AADR/CADR Annual Meeting}

Date: 3-6 March 2010

Venue: Walter E. Washington

Convention Center, Washington DC

http://aadronline.org

World of Health IT Conference and Exhibition

Date: 15-18 March 2010

Venue: The Convention Centre,

CCIB, Barcelona

www.worldofhealthit.org

The Dentistry Show

Date: 19-20 March 2010

Venue: NEC Birmingham

www.thedentistryshow.co.uk

\title{
BDTA WELCOMES NEW PRESIDENT
}

The British Dental Trade Association (BDTA) has recently announced the inauguration of its new President, Edward Attenborough. Edward was welcomed by the membership at the Association's Midwinter Meeting in London in December, with his Presidency officially commencing on 1 January 2010. He takes over from Simon Gambold, Managing Director of Henry Schein Dental, who has served as President since 2007.

Commenting on the handover, Edward Attenborough said, 'Simon has strengthened our links with the professional associations and worked hard to improve our lobbying capabilities and self regulation within the membership. I aim to continue with the focus on quality standards in both the surgery and laboratory sides of the industry as well as meeting the needs of the membership.'

\section{SOCIETY KEEPS UP US LINKS}

The American Dental Society of London (ADSL) recently celebrated its 102nd anniversary and installed Dr Guy Robertson as its new President for the coming season. It is an association of dentists who have studied in the USA or Canada, and is instituted for the study and discussion of dentistry and its allied arts and sciences.
Edward, Managing Director of Attenborough Dental, will be supported in his role by Vice-President Karen Turner, Managing Director of Dentafix.



The ADSL hold regular lecture evenings given by internationally recognised speakers on a wide range of dental topics. These lectures are continuing education accredited, and include a sit down dinner and discussion. There is also an annual social event.

The ADSL maintains a close relationship with the American Dental Society of Europe and the American Dental Club of Paris. For further information visit www.adslondon.org.

\section{FOCUS ON CLINICAL AUDIT}

Phillip Cannell, a GDP in Leigh-on-Sea, Essex and Senior Lecturer in the School

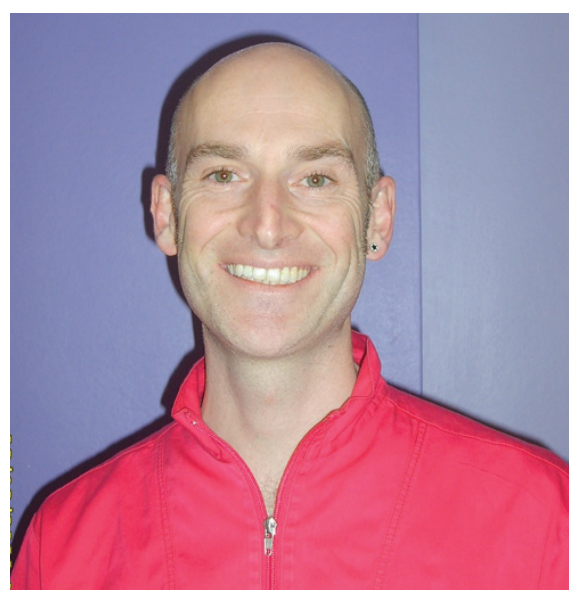

of Health and Human Sciences (SHHS) at the University of Essex, has recently published the results of a three year research project evaluating dentists' experiences of undertaking clinical audit in both the post-2001 GDS scheme and in an NHS modernisation agency pilot clinical audit scheme run within South East Essex PCT.

The research concludes by providing recommendations for the future design and use of clinical audit in dentistry, which it is hoped will assist both those commissioning future audit programmes and those embarking on clinical audit projects. A full copy of the report is available from the BDA library. 